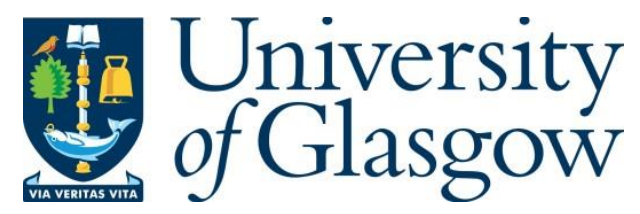

Robinson, P. A. (2017) Framing bovine tuberculosis: a 'political ecology of health' approach to circulation of knowledge(s) about animal disease control. Geographical Journal, 183(3), pp. 285-294.

There may be differences between this version and the published version. You are advised to consult the publisher's version if you wish to cite from it.

This is the peer reviewed version of the following article Robinson, P. A. (2017) Framing bovine tuberculosis: a 'political ecology of health' approach to circulation of knowledge(s) about animal disease control. Geographical Journal, 183(3), pp. 285-294, which has been published in final form at http://dx.doi.org/10.1111/geoj.12217. This article may be used for non-commercial purposes in accordance with Wiley Terms and Conditions for Self-Archiving.

http://eprints.gla.ac.uk/201480/

Deposited on: 4 December 2019

Enlighten - Research publications by members of the University of Glasgow http://eprints.gla.ac.uk 


\title{
Framing bovine tuberculosis: a 'political ecology of health' approach to circulation of knowledge(s) about animal disease control
}

\author{
Philip A. Robinson \\ Harper Adams University, Newport, Shropshire, UK.
}

\begin{abstract}
Bovine tuberculosis (bTB) remains a significant animal health problem with a global distribution. In addition to the ecological complexities, socioeconomic and sociocultural factors also affect efforts to control and eliminate the disease. Interrogating bTB from the author's positionality of being both a veterinary epidemiologist and a human geographer, this interdisciplinary engagement in the political ecology of health investigates the experiences and opinions of the actors involved in disease control. The findings of this research in one part of the United Kingdom - Northern Ireland - demonstrate gaps between expert scientific discourse and circulating on-the-ground perceptions and lay knowledges of the disease. bTB is therefore known and framed in multiple, often antithetical, ways by those who meet and experience the disease on farms. The paper concludes that farmers, vets and state policy makers must accept the heterogeneity of the disease; make it visible again; and create new imaginaries for a future where bTB is no longer an everyday ubiquity.
\end{abstract}

\section{Keywords}

Bovine tuberculosis, biosecurity, framing, knowledge circulations, political ecology of health, Science and Technology Studies 


\section{Introduction}

Bovine tuberculosis (bTB), an infectious disease of cattle caused by the bacterium Mycobacterium bovis, is an animal health problem with global significance. The disease is endemic in many countries in the Global South, and has been problematic to control in regions of developed nations such as the United Kingdom (UK), Republic of Ireland, Spain, France, USA and New Zealand in the recent past or present, although most countries in the Global North are officially disease-free, with only sporadic cases in cattle. It has a long history, and since Robert Koch cultured the tubercle bacillus in a laboratory in 1882 (Collins and Grange 1983), bTB has been the focus of intense research interest, and much controversy on how to resolve it (Atkins 2016).

bTB has significant economic implications for animal agriculture. Within the European Union (EU), legislation requires the eradication of bTB from the territories of Member States, primarily to facilitate the free trade of animals and animal products, but also traditionally and historically to protect human health. The statutory programme in Northern Ireland (N. Ireland) began in 1959 with the aim of eradicating the disease (see Robinson 2015), but nearly six decades later, bTB remains an expensive and frustrating problem for cattle farmers, state veterinary authorities, politicians and policy makers. All cattle are required by legislation to be tested at least annually for the disease at the state's expense, and positive animals are removed for slaughter with compensation to affected herd owners. For example, £317M (US\$ 386M) was spent by the state on the Northern Irish control programme between 1996 and 2011 (NI Assembly 2012), and that figure does not include the cost to farmers of herd restrictions and loss of trade. Although only a relatively small percentage of cattle herds is diseased at any one time (cumulative herd 
incidence $7.45 \%$ in 2016 in N. Ireland), it is still a significant economic problem (DAERA 2016). With the involvement of a wildlife reservoir of infection in the European badger (Meles meles), it also has controversial environmental dimensions through the debate on what to do about the badger, particularly on whether it should be vaccinated or culled (O’Hagan et al. 2016a).

In addition to the ecological challenges, a failure to eliminate bTB in the UK is also due to complex socioeconomic, sociocultural and political contingencies connecting farmers, vets, the state and the wider political economy of intensive agricultural livestock production systems. These factors are poorly understood for bTB, and a review of the natural science evidence base acknowledged the importance and need for further social science research to help plot a way forward (Godfray et al. 2013, 4). Social scientists have certainly been doing much to unravel the problem in England and Wales (eg Cassidy 2015; Enticott 2008; Enticott et al. 2012; Fisher 2013; Maye et al. 2014), but the scale and complexity of this often political disease leaves room for further untangling, even within the UK. Further consideration needs to be given, for example, to the failure to force a microbe into submission because of its intrinsically unruly and unpredictable behaviours - an aspect of the disease which is underappreciated by perhaps the majority of stakeholders. More emphasis needs to be placed on on-the-ground experience and perception of the pathogen and the disease that biosecurity measures aim to discipline.

With a background as a state veterinarian and veterinary epidemiologist, but conducting the research from within the discipline of human geography as a political ecologist, my purpose in this paper is therefore to analyse and explain how we may better know disease by learning from those who view and experience it in different ways at ground level in $\mathrm{N}$. 
Ireland. What is this disease that state veterinarians seek to eliminate? How is the disease framed in space and time on the farm, in the veterinary clinic, and in the state veterinary office? What are its impacts? These findings are important, for as Moda (2006) has suggested elsewhere in Europe, social, non-technical, factors have an influence on bTB programme success, and Robinson (2015) has already demonstrated that for this longstanding and intractable problem in N. Ireland, socioeconomic factors have had an important influence on the history of control. Are the political ecology of the disease and how it is perceived important factors in the conundrum of much effort for many years with less-than-satisfactory results?

\section{Political ecology and the framing of a disease}

Political ecologists have increasingly been influenced by research in Science and Technology Studies (STS). Merging methodologies and insights from STS can benefit political ecology by premising that knowledge is situated; expertise can be challenged in different contexts; knowledge circulates through networks; science and society are coproduced; and knowledge is political (Goldman and Turner, 2011: 14). Peet et al. (2011, 34) describe how political ecology has been increasingly concerned about environmental representation and practice, and how 'human knowledge of the environment can be interpreted, controlled and indeed manipulated'. In a similar vein, and emphasizing the politics of knowledge, Goldman and Turner $(2011,1)$ remind us that 'knowing nature is a complex, multiple, and highly political process’.

Despite the complexity, Robbins $(2015,91)$ posits that political ecology can help to 'map the power-laden source and circulations of discourses and legitimate authority that forge 
ecological truth'. There is therefore particular merit in examining the knowledges that circulate amongst the different actors in an environmental problem (Turner, 2011) if long-held assumptions and over-simplifications of nature-society entanglements are to be challenged; as is fundamental to the work of political ecologists. Tracing the genealogies and developing agendas of political ecology, Bridge et al. $(2015,5)$, argue that it (perhaps above all) has, and continues to, define itself as 'an epistemological project which set out to shatter comfortable and simplistic "truths" about the relationship between society and its natural environment'. Environmental politics therefore involves engaging with knowledge and truth claims, observations and experiences thrown into a melting pot by those concerned with the issue in question. This is important, for the complex and potentially conflicting knowledge politics of bTB have the potential to 'shape contestations and outcomes' (Goldman and Turner 2011, 2) in the management of this disease, and it is therefore vital that these framings and discourses of bTB are identified.

Significantly, this paper answers the calls of King (2010) and King and Crews (2013) to uncover the social and environmental narratives and discourses of actors and institutions in relation to disease. Jackson and Neely (2014) and Connolly et al. (2017) encourage a political ecology of health influenced by STS which can better interrogate place-based partial and situated knowledges, and this approach has been taken up with respect to other mycobacterial diseases. For example, Neely (2014) has researched human TB in South Africa caused by Mycobacterium tuberculosis, and Hausermann (2015) has investigated the assemblages constituted by Mycobacterium ulcerans and Buruli ulcer in Ghana. Connolly (2017), also influenced by STS literatures, specifically analyses the competing stakeholder discourses of disease in relation to urban bird farming in Malaysia 
and the perceived risks to human health. Bovine tuberculosis is also a complex environment-society problem, and approaching the problem through a political ecology influenced by STS provides new perspectives on Mycobacterium bovis disease ecology.

Although the professionals may profess to 'know better than others the nature of certain matters' (Hughes 1971, 375), for our purposes it is vitally important that all knowledges and realities of bTB - scientific and practical; abstract 'techne' and earthy 'mētis' knowledges (Scott 1998, 311) - are analysed together. While people may differ on how they 'interpret the world they live in' (Mol 2002, 10), the boundaries between expert and lay epistemologies are often difficult to define (McKechnie 2003); their perspectives on disease often overlap, but can also diverge and contradict. The aim is also to bring to the fore voices which may otherwise remain marginalized (Wynne 1996), drawing forth alternative framings of the disease which may not register in current scientific and political discourses. Shmueli $(2008,2048)$ defines framing as 'a cognitive process whereby individuals and groups filter their perceptions, interpretations and understandings of complex situations in ways consistent with their own socio-political, economic and cultural world views and experiences'. Used in this way, framing becomes a device acting as an 'interpretative lens' (Buijs et al. 2011, 330), demonstrating how different people can have different perspectives on the same subject (Emery et al. 2013). Framing has been used in human health contexts to study disease epidemics (e.g. Dry and Leach 2010a; Leach and Tadros 2014). Indeed, the framing of disease within medical history, sociology and anthropology has a long history (Aronowitz 2008).

The focus in this paper is therefore on exploring what bTB is, and how its behaviours are framed to provide the ecology and ethnography of a disease. I consider not so much the 
complexity of the factors comprising the 'web of causation' (Pfeiffer 2013), but rather the contested knowledges and narratives of bTB. I follow it through the disease network and find it to be much more than the 'infectious, granulomatous disease caused by acid-fast bacilli of the genus Mycobacterium' of scientific discourse (Anon 2005, 549). As Leach (2007) suggests, 'grounded' knowledges may contradict 'scientific' knowledges, and 'framings [of bTB] ... are plural, contingent and conditioned by divergent values, interests, [and] disciplinary perspectives' (Leach et al. 2010, 375). From such a perspective, we produce a more-than-human political ecology of animal health.

\section{Data collection and analysis}

The findings presented in this paper are based on in-depth individual or multi-person interviews ( $\mathrm{n}=60$ ) and two focus group interviews, which primarily involved dairy and beef cattle farmers ( $n=47)$, and private practice and state veterinarians $(n=30)$, as part of a social science investigation of why bTB had not yet been eradicated from N. Ireland. These interviews were conducted by the author between September 2012 and May 2013 in both high and low incidence areas of bTB in cattle across N. Ireland. They were semistructured in style, and audio-recorded with informed consent. The interviewees were initially selected through personal contact networks of the author in both the farming and veterinary communities in N. Ireland, who in turn invited other possible interviewees through snowball sampling, seeking purposively to sample a range of experiences and views from different types and size of farms, with various histories of bTB, and in different parts of the country.

This was not merely a case of understanding and collecting data. Whatmore $(2003,90)$ 
argues that research is 'an intervention in the world' and the generation of data is a 'cofabrication' between researcher and researched. As a researcher with a background in the subject and object of my research I was very aware that both farmers and vets were keen to work out the problem of bTB, keen to see progress being made, and offering hope that perhaps, in some sense, we could work this out together. The following interchange with a farmer illustrates the nature of the detective work that we were 'co-fabricating' through the research interviews, but emphasizes the mystery of what we were producing because of the complexity of the disease epidemiology we were seeking to unravel:

Farmer: 'Is there anybody ... can you get to the bottom of it?'

Auth: 'Not yet [laughs]'

Farmer: 'It will be interesting for you to go ahead and get to the bottom of it ... [but] somewhere along the line you'll find something to knock you all wrong' (Int A34, beef farmer)

All of the interviews were fully transcribed using $f 4$ transcription software (audiotranskription.de), coded thematically using Nvivo software (Version 9, QSR International Ltd.), and analysed using a grounded theory approach (Glaser and Strauss 2008). In the remainder of this paper I present the perspectives, events and practices of bTB using a three-fold framing of the disease: mysterious heterogeneity; vague imaginary; and everyday ubiquity. These framings emerged from the empirical findings of the qualitative interviews and so were data-driven. The practice of veterinary ethnography provides alternative understandings, alternative framings, in this political ecology of bTB. 


\section{Results}

\section{Frame 1: Mysterious heterogeneity - coming, and going}

The overall aim of the state scheme is to eliminate transmission between animals and herds, and in the early years, when it still had voluntary participation by farmers keen to move ahead, the NI Ministry of Agriculture enthusiastically declared that 'it is now apparent that tuberculosis in cattle is a disease which lends itself to practical control measures' (MANI 1951, 270). After decades of applying 'practical control measures' such as the testing, quarantine and removal of infected animals and herd trading restrictions to reduce contagion, such confidence has all but evaporated after many years of effort, although one state vet still believed that the disease and its control was 'straightforward' (Int A61). The first framing therefore concerns the heterogeneous transmission of the disease between and within herds of cattle, and the contrasting views on the predictability of the transmissions.

bTB is often referred to as an infectious disease in state discourses. Indeed the opening line of the N. Ireland Assembly’s Agriculture and Rural Development Committee Review into bTB declared that it is 'a highly infectious disease [emphasis added]' (NI Assembly 2012, 1). bTB has the potential to erupt, to boil over, to spill, and bTB elimination efforts often seem to be merely keeping the lid on an effervescent tin can to reduce over-spill. bTB testing of cattle is the tool the state and private vets put their faith in to try to detect presence and remove positives (known as 'reactors') before it becomes a herd eruption. If this is done often enough, the lid can be kept on, but it seems an ever-present reality requiring intensive and sustained effort: 
'We did try to improve our control by intensive testing areas and that sort of thing ... doing that did bring the bTB incidence down, but the minute you take your foot off the pedal off it goes again. The minute you move away from intensive testing of cattle then the disease [incidence] rises.' (Int A61, state vet)

Efforts to control bTB illustrate the messiness of seeking to 'control nature', and resonates with the tendency of the things of nature 'striking back' (Latour 2000). This is particularly so when we think of bTB's heterogeneous practices of coming and going, or to put it another way, appearing and disappearing. It may appear to be a binary logic present or absent - but it is a rather more fluid gradient, and there is a mystique and heterogeneity about bTB's transmission which makes it more complicated to know. According to both farmers and vets, arrival is often unannounced from a deep blue yonder:

'At our annual test in January ... we lost ... I think it was 42 that first day - all milk cows, and that was a bolt out of the blue, because, as I say, bTB hasn't been a problem on this farm ...' (Int A8, dairy farmer)

'I have had quite a few interesting breakdowns, where the guy has been good for years, buys nothing, has no interactions except along his fence line with his neighbours ... and out of the blue he could have a spectacular breakdown.' (Int A19, private vet)

Others were less shocked by the arrival of the disease, and indeed, as we shall see later, it was a commonplace ubiquity which was almost expected. Warning signs for some were the presence on a neighbouring farm or in the local area, or it occurred with 'monotonous regularity' on the same farm (Int A49, private vet) - every test, it seemed, had the same 
positive result. As a result, one vet felt that farmers in some areas were so used to bTB they were prepared for reactors to be revealed at any and every herd test, but other vets still expressed surprise when they found reactors. This reflects the spatiotemporal variance in bTB herd incidence across N. Ireland. For example, a vet in a historically low incidence region said:

'When a reactor shows up, usually we get a surprise: “Good grief, it's there!” ... Certainly any time reactors have come up I've been quite surprised: “Oh, too bad, it's a reactor!”' (A49, private vet)

bTB's arrival may be a surprise, but is it a predictable one that farmers should have seen coming and prepared for? Farmers often felt helpless when asked about preventing bTB, but influencing this belief must surely be the unpredictability of its presence on farms. One very experienced beef farmer (A21), under bTB positive herd restriction at the time of the interview, explicitly connected this sense of uncontrollability and the unpredictability of the disease's presence during the breakdown, as vividly illustrated by this interchange:

Auth: 'Is there anything you think a farmer can do to keep bTB out of his herd? Farmer: 'No.'

Auth: 'Nothing?'

Farmer: 'No, absolutely nothing, no. For how can bTB appear in my pen ... if I put 10 cattle in a pen, and one animal has it, how did it get in, and why do the other 9 not have it ... you know?'

Auth: 'Yes, so what you are saying is that you are sceptical about how infectious bTB actually is?' 
Farmer: 'Yes, it's not spreading. bTB should be spreading round my farm - I should have had 17 that week, and the next time I tested I should have had 34 or 44 or 54, you know. But instead of that it drops. If there was some one animal there doing the damage - it should have had all the damage done? Like the whole herd should nearly be ...' Auth: 'So it's unpredictable?'

Farmer: 'Oh it's definitely unpredictable here anyway: different animals, different ages, different yards, different houses, and some up the road then not related to it at all.' (Int A21, beef farmer)

There was therefore an unexplained heterogeneity about the nature of the outbreak which made no sense, and had no logic, leading to a declaration of impotence in the face of such unknowable force. The scientific discourse of an infectious disease was apparently contradicted by on-the-ground reality - the highly infectious disease was not spreading as the farmers expected it to.

If arrival is unexpected and hard to predict, departure can be equally so, leading to further perplexity and confusion. There were often no answers as to where bTB came from, why it left, and when it could next appear:

'We don't know where it came from, and I think it seems to be indiscriminate and it can just turn up. Now you are not looking forward to your next test. I never really looked forward to testing, but it's starting to play on [my] mind.’ (Int A8, dairy farmer)

bTB was gone, for a while at least, even if it took some time to sink in, but who could tell when it would re-appear? Such are the mysterious comings and goings of the disease 
which surprise, perplex, and unsettle both farmers and vets.

\section{Frame 2: Vague imaginary - hiding, or not}

The second framing concerns the visibility (or lack) of bTB outside of veterinary laboratories and cattle abattoirs. State vets often expressed their frustration that many farmers did not follow official veterinary advice on biosecurity measures to exclude bTB from entering their herds, and to reduce spread within herds post-detection. In short, there appeared to be a distinct lack of 'buy-in' to the benefits of bTB control for the future prospects of the dairy and beef industries in N. Ireland. Some state vets thought that the solution was to provide more and better information to address the perceived knowledge deficit and lack of engagement. Seeking to answer the 'why' question on the perceived lack of attention to biosecurity, a view amongst several vets was that bTB was not a 'real' disease in the eyes of farmers - it was a vague imaginary, almost a figment of the state's imagination, and of vets in general. This hiding was thought to affect farmer beliefs and behaviours:

'If the farmer doesn't believe that it's a disease, a real disease, a real infectious disease, is it any surprise that he won't double fence, or that he won't operate a closed herd, or that he won't put [disinfectant] foot baths at each [cattle shed]?' (Int A42, state vet)

Auth: 'What's the farmers' attitude to bTB in general?'

Vet: 'I think they see it as a nuisance. I think they see the testing process as a nuisance. I think they don't really believe that animals actually have bTB.' 
Auth: 'Because there's nothing to see?'

Vet: ‘There's no disease. You know, I’ve never seen an animal with clinical bTB. And the number of clients of mine that have is declining every year. There are some - there are people who do remember the days before bTB eradication. And I still have clients who have had [human] TB and talk about it, but it's a declining number. I don't think ... I don't think they have any clear view ... you know, it happens, they have to do the bTB test ...' (Int A48, private vet)

The fact that there are very rarely obvious clinical signs in cattle, and disease in humans is virtually never seen, means that farmers (at least to some degree) may no longer believe in the disease's existence beyond the results of a bTB test - bTB is hiding its presence. In one sense, the bTB control programme is a victim of its own success, making it harder to remove the rump of persistent disease that remains. This interpretation was supported by a beef farmer who complained bitterly about having to bTB test his large herd on a very regular basis, and he questioned the need for the programme in general. For him, bTB was an invisible disease - there was nothing to see, and he did not know what to look for anyway:

'Those eleven [bTB reactors] ... they were all fit and healthy animals, you wouldn't have picked them out, and they went on their way ... [pause] ... If an animal is really sick with bTB, what does it show?' (Int A38, beef farmer)

This lack of anything rendered visible contrasted to other diseases more commonly encountered on the farm, as state vets explained concerning Bovine Viral Diarrhoea (BVD) - another cattle disease - whose presence was thought to be more obvious:

Vet 5: 'Most farmers if they [look] back over their herd over the years they will 
recall seeing an animal with BVD and the consequences of it. ... Even if you've seen it once you would remember what type of thing it is, whereas with the bTB you don't see it //

Vet 2: 'You don't see it. bTB is not an illness, whereas BVD is - it kills their cattle.'

Vet 3: 'That's true.'

Vet 4: 'And it costs them money which they don't get compensated for.' (Int A43, state vets focus group)

When I questioned farmers in a focus group on the 'reality' of bTB in their eyes, they denied that they viewed it as anything other than a 'real' disease, so perhaps it is more complicated and nuanced than the vets believe, or there is a disconnect between what is admitted and what is acted upon subconsciously. There was certainly a high degree of animal disease awareness in general amongst the farmers interviewed, and vaccination was used widely as a means to prevent or lessen the effects of common endemic diseases (e.g. BVD, infectious bovine rhinotracheitis and leptospirosis), especially in the dairy sector. There was a common 'safety first' approach to protecting their most important assets - the cattle - and minimizing the economic effects of disease outbreaks. But no vaccine is yet available for bTB in the UK, and perhaps this encouraged a belief that nothing can be done to halt the spread of bTB. What also comes into the equation is the economic impact that bTB may or may not have on a farm in comparison with other diseases:

Farmer 2: ‘Actually, with biosecurity my first thought isn't bTB, my first thought is the other diseases - Johne's [disease] and all the rest, actually, because they 
have a much greater potential to really affect my bottom line [profit] - if I get IBR [Infectious Bovine Rhinotracheitis] or Johne's or BVD or whatever - and I vaccinate as much as I can - economically that would have a much greater economic impact on me than bTB. Those other things would make me think much more about biosecurity.' (Int A58, farmer focus group)

Rather than underestimating the presence of bTB or lacking knowledge of the epidemiology of the disease, there may be some degree of calculation amongst farmers that trying to stop bTB is indeed a waste of their time and resources. Discussing the perception of risk, anthropologist Mary Douglas (2003, 29-30) states that: 'Apparently, people underestimate risks which are supposed to be under their control. They reckon they can cope with familiar situations. They also underestimate risks which are rarely expected to happen ... Most common everyday dangers tend to be ignored ... neglecting low-frequency events seems an eminently reasonable strategy'. bTB, may be hidden, but it may never appear at all, and even if it does, it can often be coped with, at least for a time. If bTB is hiding, many are willing to ignore or forget, because there is much more that is visible, catching the immediate attention, and with more economic impact in the present. With around 93\% of herds free of bTB at any given time, the risk of acquiring it may appear low, even when purchasing animals from other herds. Risk decisions and economic consequences therefore appear to be connected. In a farmer's mind, an 'eminently reasonable strategy' may indeed be in place to suit the trading pressures and economic realities of modern cattle farming in a pressurized market.

\section{Frame 3: Everyday ubiquity - desensitizing}

Our third framing concerns the attitude, particularly prevalent amongst farmers, that bTB 
in N. Ireland, despite the intense eradication efforts, is apparently never going to disappear. As already outlined, for many farmers bTB is part of everyday farming life. There has been heightened awareness of bTB for over a century in Ireland, and the disease may therefore be regarded as almost omnipresent in space and time, but that does not guarantee understanding of what the presence is or means. Elden's work on the French philosopher Henri Lefebvre points out that: 'Lefebvre acknowledges the importance of Hegel’s dictum: “The familiar [das Bekannte], just because it is familiar [bekannt], is not well known [erkannt]”. Everyday life may be familiar to us but this does not mean that it is understood' (Elden 2004, 111). And so it is with bTB, the disease which is not well known, and not well understood, despite its everyday appearances and familiarity to many farmers. In a sense, bTB desensitizes by its ubiquity and confusing un-knowability, leading to an almost resigned acceptance:

'Now it's a fact of life, but life goes on. There are a lot of things in life people don't like, but OK, you complain, but after a year or two it's a fact of life, and things carry on. There probably will be some sort of cost-sharing done eventually [with the state], and maybe if the farmer had to help to pay for it, or had to pay for it ... maybe it might concentrate his mind more actually on the disease and what he can do himself.' (Int A10, private vet)

'Everybody wants to have a clear test, and if you are down, well, it's a nuisance, but it's an accepted thing, that it's a part of ... it's been going on for a lifetime, but it's one of those things that has gone on and on and has still not resolved.' (Int A3, dairy farmer)

Here it is described as 'an accepted thing' with no resolution because it has gone on for 
many years with no end in sight. Some farms experience bTB 'with monotonous regularity' (Int A49, private vet), and farmers, and vets, have become desensitized as they metaphorically shrug their shoulders and suggest they have 'bumbled along ... just accept[ing] this is where we are' (Int A56, state vet). For many it seems hard to escape the anaesthetizing effect of everyday reality, and bTB keeps on coming back. This leads to feelings of despair that it will, or can ever, be any better:

'Sure we have been working at it for I don't know how many years, and they haven't managed it yet ... and it still doesn't seem to be getting any better, so I don't really see how they are going to eradicate it.' (Int A28, dairy farmer)

'Well, they have been testing here since a long number of years - what have they achieved? They've achieved nothing. bTB is as rife now as it was 40 years ago. I thought this business of testing was to eradicate the bTB out of the dairy herd?' (Int A5, dairy farmer)

Part of the despair stems from bTB often being described as ‘a multifactorial disease' (Int A47, Int A51, Int A55, A61), leading one vet to cry with exasperation: 'If I hear “multifactorial” one more time I'm going to scream' (Int A41, state vet). Alongside rhetorics of scientific complexity, this is used as a common explanation by the state to justify why bTB has thus far escaped elimination.

\section{Discussion}

Examining the framings of bTB reveals how the multiple versions of what bTB is often perplex the actors involved, and makes 'get(ting) to the bottom of it' a particular challenge. Not everyone is apparently seeing or experiencing the same disease, with ‘struggles between different versions of reality’ (Law 2009, 2), or to quote Ludwik Fleck: 
'as history shows, it is feasible to introduce completely different classifications of diseases' (Fleck 1979, 21). Indeed, Fleck went so far as to suggest that 'a uniform understanding of morbidity is impossible’ (Fleck 1927, cited in Löwy 1988, 141). Clearly, as suggested in the introduction, these multiple framings go beyond the scientific discourse of an infectious granulomatous disease caused by Mycobacterium bovis. As demonstrated through the thoughts and experiences of the interviewees, it is much else besides. bTB confuses - it is a mysterious heterogeneity and a vague imaginary, hiding from view, challenging the state veterinary authorities on how to make it more 'real'. For many, bTB is an everyday ubiquity, part of everyday farming life, and something to be coped with, and tolerated, rather than driven relentlessly towards elimination. This attitude markedly contrasts with the attitude at the end of the very successful first decade of the statutory programme in the late 1960s, when it was believed that bTB in N. Ireland was a problem of the past (Robinson 2015).

It is difficult to pin down and neatly delineate bTB, and this complexity adds to the difficulty (or perhaps explains) why bTB has proven so difficult to govern. For farmers (and vets) adept at finding solutions and solving problems through their grounded and practical know-how, bTB may appear beyond their power to affect change because it is often invisible and amorphous. Governance is particularly difficult in such circumstances of perplexity and multiplicity - what is bTB; how is it to be understood; and can it be eliminated? As Dry and Leach (2010b, 244) declare: 'Long wars - against diseases as well as nations - are unpopular'. Perhaps no one really knows what object they are trying to remove from everyday life on the farm, which disease narrative to believe, and how therefore to go about it. This is part of the reason why bTB has not yet been eliminated, 
but revealing and engaging with the 'complementary and additional understandings' (Leach et al. 2010, 375) from ground level actors is important if new governance agendas are to be introduced in the future. Efforts to improve diagnostics and develop vaccines are important tools in the future struggle to contain bTB, but this ongoing scientific work must be complemented by a better understanding of the attitudes and beliefs of the people involved, and the behaviours of the bacterium and disease which they seek to control and ultimately eliminate. Based on the findings of these in-depth qualitative and ethnographic interviews with actors in bTB control, this paper suggests that three key things need to change if progress towards elimination is to be achieved.

First, the bTB programme and its participants must cope better with the disease's recalcitrant heterogeneity. It is not a particularly predictable entity, and its transmissions are often surprising: not every herd or animal will be infected when challenged, and not every herd or animal will develop a positive immune response to the presence or past exposure to bTB when tested. This behaviour confuses farmers and encourages them to adopt fatalistic attitudes about bTB being uncontrollable, as revealed in other bTB research elsewhere in the UK (Enticott and Vanclay 2011). Arguably, to some extent it is, but there are known biosecurity measures that can be adopted by farmers to greatly reduce the risk of bTB incursion into their herds (O'Hagan et al. 2016b), although the same prescribed methods may not work on every farm. An approach embracing heterogeneity 'emphasizes that ... networks of complex social and technological systems, such as disease containment, are often open, emergent and highly context specific, and therefore consistently defy prediction and control' (Fish et al. 2011, 2027). In such systems (and bTB control is one of them), uncertainties abound, but there are ways and 
means of managing and adapting to those uncertainties to bring order and control from apparent chaos. This must be nuanced and adapted to each farm scenario by farmers and vets expertly working in partnership, with clear justification and practicality to ensure farmer adoption.

Second, I suggest that the disease has been pushed into the background by veterinary and administrative practice, and there is a need to make bTB more real by making it visible again. Ironically, the control programme has become a victim of its own success over time. The lack of a visible bTB presence on farms in terms of clinical cases (coughing, wasting, dying cattle) as seen historically (Atkins 2016) proves that early testing and removal of positives prevents animals from advancing to clinical stages of disease, but this has rendered the disease virtually invisible to farmers (and vets). Its impacts are uneven across farms - some experience it, others don't, and to varying degrees of impact within herds even in the same locales, leading some to question whether its apparent presence is genuine. This need to more clearly visualize the disease was recognized in early efforts to eliminate tuberculosis in both humans and animals at the beginning of the $20^{\text {th }}$ century in Ireland. An early campaign was organized by Lady Aberdeen (18571939), primarily against the human form of TB. It began with an exhibition in Dublin in October 1907, moved to towns in the north of Ireland, and then was taken by horsedrawn caravan around the rest of Ireland (Breathnach and Moynihan 2012). The aim was to render the disease visible, based on the premise that what is seen may be better understood. Today's generation of farmers and vets have forgotten what bTB in cattle looks or sounds like - it is merely a skin swelling in the neck after reaction to a tuberculin test injection. There is nothing else to see until the carcass is opened, and even then the 
lesions may remain hidden from the view, lurking unseen within organs or glands.

Third, the future has to be different from the past. Some think that 'the disease is very straightforward' (Int A61, state vet). I would argue the opposite: there are differing versions and spatialities of bTB, making it a messy complexity, for as Mol and Law (2002, 1) suggest: 'There is complexity if things relate but don't add up, if events occur but not within the processes of linear time, and if phenomena share a space but cannot be mapped in terms of a single set of three-dimensional coordinates'. Surely bTB aptly fits the description, but the question is what to do about it? As stated already, there must be acceptance of, and adaptation to cope with, heterogeneity, and a need to make the disease visible again, but through visionary leadership there must surely also be the creation, promotion, and adoption of new imaginaries of a life beyond bTB as an everyday ubiquity in the lives of farmers and vets (and cattle) in N. Ireland. Without engendering the vision that bTB can ever be anything else but an everyday presence, the policy may be doomed to further years of frustrated toil and aspiration, with less-than-satisfactory results. Learning from successful examples of highly-motivated partnership approaches between the state, vets and farmers towards bTB eradication in other countries such as Australia (where the disease was eradicated in 1997) (More et al. 2015), and New Zealand (Livingstone et al. 2015) provides valuable lessons which can be adapted to $\mathrm{N}$. Ireland.

\section{Conclusion}

This paper has demonstrated the value of unravelling the politics and ecology of disease, revealing alternative framings of bTB. An approach based on a political ecology of health 
helps with the 'rigorous pursuit of knowledge in a world filled with contradictions' (Robbins, 2015, 98). These contradictions must be accepted and better understood if disease governance is to be more successful in the future than it has been in the recent past and present. The conflicted framings of the disease mean that 'one-size-fits-all' approaches to control policy are unlikely to succeed with bTB. Instead, mirroring the disease itself, 'policy must be necessarily plural and conditional' (Leach and Scoones 2013, 16). In the end, whose (and which) reality counts? The answer to this question has importance for the prospects of further progress towards bTB elimination, not just in $\mathrm{N}$. Ireland, but wherever any disease elimination or eradication programme is in operation. This is especially relevant for those having dealt with recalcitrant diseases over long periods of time, where the lack of resolution has produced despair and disengagement. Such ethnographic perspectives on disease control provide new understandings which can profitably be applied to the policy context, and guide efforts to improve knowledge transfer and co-operation between state authorities and farmers and vets on the frontline of control. The increasing recognition and appreciation of social science research by policy makers, veterinary scientists, and epidemiologists offers hope that progress can be made on bTB on multiple fronts through a deeper and richer understanding and utilisation of the knowledge circulations of the actors involved. The role of the badger in the spread of bTB has caused much political and scientific controversy, but there is surely more to the bTB problem than solely debating what to do about the badger? It is time to recalibrate and refocus on the disease and the people who experience it in the field; there are other framings which also need to be addressed. Political ecology, framed as the 'Trickster science' by Robbins $(2015,91)$, proves its worth as both 'a rigorous participant 
in the advancement of scientific knowledge and a relentless critic of scientific ecological practice.’

\section{Acknowledgements}

Funding for this $\mathrm{PhD}$ research was generously provided by the Department of Agriculture, Environment and Rural Affairs (DAERA) in N. Ireland. Additional funding for fieldwork was provided by the Dudley Stamp Memorial Fund, UK. Ethical approval was provided by the Department of Geography at Durham University. The research was supervised by Prof. Peter Atkins, Prof. Gavin Bridge and Dr. Divya Tolia-Kelly at Durham University, whose help and guidance I very gratefully acknowledge. I also sincerely thank the editor and reviewers for their very helpful comments, and the research participants who gave their consent to be interviewed for their views and experiences of bTB in N. Ireland.

\section{References}

Anon 2005. Mycobacterium bovis in Kahn CM and Line S eds The Merck Veterinary Manual Ninth edition Merck and Co. Inc, Whitehouse Station NJ

Aronowitz R 2008 Framing disease: an underappreciated mechanism for the social patterning of health Social Science and Medicine 67 1-9

Atkins PJ 2016 A History of Uncertainty: Bovine tuberculosis in Britain 1850 to the Present Winchester University Press, Winchester

Breathnach CS and Moynihan JB 2012 The frustration of Lady Aberdeen in her crusade against tuberculosis in Ireland Ulster Medical Journal 81 37-47 
Bridge G, McCarthy J and Perreault T 2015 Editors' introduction in McCarthy J, Bridge G, and Perreault T The Routledge Handbook of Political Ecology Routledge London and New York 1-18

Buijs AE, Arts BJM, Elands BHM and Lengkeek J 2011 Beyond environmental frames: the social representation and cultural resonance of nature in conflicts over a Dutch woodland Geoforum 42 329-341

Cassidy A 2015 'Big science’ in the field: experimenting with badgers and bovine TB, 1995-2015 History and Philosophy of the Life Sciences 37 305-325

Collins CH and Grange JM 1983 A review: the bovine tubercle bacillus Journal of Applied Bacteriology 55 13-29

Connolly C 2017 "Bird cages and boiling pots for potential diseases": contested ecologies of urban 'Swiftlet farming' in George Town, Malaysia Journal of Political Ecology 24 24-43

Connolly C, Kotsila P and D’Alisa G 2017 Tracing narratives and perceptions in the political ecologies of health and disease Journal of Political Ecology 24 1-10

DAERA 2016 Bovine tuberculosis in Northern Ireland: 2015 Annual Report (https://www.daerani.gov.uk/sites/default/files/publications/daera/16.17.158\%20Bovine\%20Tuberculosis\%2 0TB\%20Annual\%20Report\%202015\%20proof\%206_1.pdf Accessed 4 April 2017

Douglas M 2003 Risk Acceptability according to the Social Sciences Mary Douglas Collected Works Vol. XI. Routledge, London and New York

Dry S and Leach M 2010a Epidemics: Science, Governance and Social Justice Earthscan, London and Washington, DC

Dry, S and M. Leach. 2010b. Towards conclusions: science, politics and social justice in 
epidemic accounts and responses in Dry S and Leach $\mathrm{M}$ eds Epidemics: Science, Governance and Social Justice Earthscan, London and Washington DC 239-256

Elden S 2004 Understanding Henri Lefebvre: Theory and the Possible. Continuum, London and New York

Emery SB, Perks MT and Bracken LJ 2013 Negotiating river restoration: the role of divergent reframing in environmental decision-making Geoforum 47 167-177

Enticott G 2008 The ecological paradox: social and natural consequences of the geographies of animal health promotion Transactions of the Institute of British Geographers 33 433-446

Enticott G and Vanclay F 2011 Scripts, animal health and biosecurity: the moral accountability of farmers' talk about animal health risks Health, Risk and Society 13 293309

Enticott G, Franklin A and Van Winden S 2012 Biosecurity and food security: spatial strategies for combating bovine tuberculosis in the UK The Geographical Journal 178 327-337

Fish R, Austin Z, Christley R, Haygarth PM, Heathwaite LA, Latham S, Medd W, Mort M, Oliver DM, Pickup R, Wastling JM and Wynne B 2011 Uncertainties in the governance of animal disease: an interdisciplinary framework for analysis Philosophical Transactions of the Royal Society B 366 2023-2034

Fisher R 2013 'A gentleman's handshake': the role of social capital and trust in transforming information into usable knowledge Journal of Rural Studies 31 13-22

Fleck L 1979 Genesis and development of a scientific fact The University of Chicago Press, Chicago and London 
Glaser BG and Strauss AL 2008 The Discovery of Grounded Theory: Strategies for Qualitative Research Aldine Transaction, New Brunswick and London

Godfray HCJ, Donnelly CA, Kao RR, Macdonald DW, McDonald RA, Petrokofsky G, Wood JLN, Woodroffe R, Young DB, and McLean AR 2013 A restatement of the natural science evidence base relevant to the control of bovine tuberculosis in Great Britain Proceedings of the Royal Society B 28020131634

Goldman MJ and Turner MD 2011 Introduction in Goldman MJ, Nadasdy $\mathbf{P}$ and Turner MD eds Knowing nature: conversations at the intersection of political ecology and science studies University of Chicago Press, Chicago and London 1-23

Hausermann HE 2015 'I could not be idle any longer': buruli ulcer treatment assemblages in rural Ghana Environment and Planning A 47 2204-2220

Hughes EC 1971 The Sociological Eye: Selected Papers Aldine Atherton Inc, Chicago and New York

Jackson P and Neely AH 2015 Triangulating health: Toward a practice of a political ecology of health Progress in Human Geography 39 47-64

King B 2010 Political ecologies of health Progress in Human Geography 34 38-55

King B and Crews KA 2013 Challenges and opportunities for future ecologies and politics of health in King $\mathbf{B}$ and Crews KA eds Ecologies and Politics of Health Routledge, London and New York 280-287

Latour B 2000 When things strike back: a possible contribution of 'science studies' to the social sciences. British Journal of Sociology 51 107-123

Law J 2009 Collateral Realities Version of 29th December 2009 (http://www.heterogeneities.net/publications/Law2009CollateralRealities.pdf) Accessed 
11 January 2017

Leach M 2007 Accommodating dissent Nature 450483

Leach M and Scoones I 2013 The social and political lives of zoonotic disease models: narratives, science and policy Social Science and Medicine 88 10-17

Leach M and Tadros M 2014 Epidemics and the politics of knowledge: contested narratives in Egypt’s H1N1 response Medical Anthropology 33 240-254

Leach M, Scoones I and Stirling A 2010 Governing epidemics in an age of complexity: narratives, politics and pathways to sustainability Global Environmental Change 20 369377

Livingstone PG, Hancox N, Nugent G and de Lisle GW 2015 Toward eradication: the effect of Mycobacterium bovis infection in wildlife on the evolution and future direction of bovine tuberculosis management in New Zealand New Zealand Veterinary Journal 63 $4-18$

Löwy I 1988 Ludwik Fleck on the social construction of medical knowledge Sociology of Heath \& Illness 10 133-155

MANI 1951 Ministry of Agriculture for Northern Ireland Monthly Reports, Volume 25, January 1951, 270-272

Maye D, Enticott G, Naylor R, Ilbery B and Kirwan J 2014 Animal disease and narratives of nature: Farmers' reactions to the neoliberal governance of bovine tuberculosis Journal of Rural Studies 36 401-410

McKechnie R 2003 Insiders and outsiders: identifying experts on home ground in Irwin A and Wynne B eds Misunderstanding Science? The Public Reconstruction of Science and Technology Cambridge University Press, Cambridge 126-151 
Moda G 2006 Non-technical constraints to eradication: the Italian experience Veterinary Microbiology 112 253-258

Mol A 2002 The Body Multiple: Ontology in Medical Practice Duke University Press, Durham NC and London

Mol A and Law J 2002 Complexities: an introduction in Law J and Mol A eds Complexities: Social Studies of Knowledge Practices Duke University Press, Durham NC and London 1-22

More SJ, Radunz B and Glanville RJ 2015 Lessons learned during the successful eradication of bovine tuberculosis from Australia Veterinary Record 177 224-232

Neely AH 2015 Internal ecologies and the limits of local biologies: A political ecology of tuberculosis in the time of AIDS Annals of the Association of American Geographers 105 791-805

NI Assembly 2012 Review into bovine tuberculosis, Volume 1, together with the minutes of proceedings of the committee relating to the summary, the minutes of evidence and correspondence. NIA 83/11-15, 13 November 2012. Agriculture and Rural Development Committee of NI Assembly, Belfast

O’Hagan MJH, Matthews DI, Laird C and McDowell SWJ 2016a Farmers' beliefs about bovine tuberculosis control in Northern Ireland The Veterinary Journal 212 22-26 O’Hagan MJH, Matthews DI, Laird C and McDowell SWJ 2016b Herd-level risk factors for bovine tuberculosis and adoption of related biosecurity measures in Northern Ireland: A case-control study The Veterinary Journal 213 26-32

Peet R, Robbins P and Watts M 2011 Global nature in Peet R, Robbins P and Watts MJ eds Global Political Ecology Routledge, London and New York 1-47 
Pfeiffer DU 2013 Epidemiology caught in the causal web of bovine tuberculosis. Transboundary and Emerging Diseases 60 104-110

Robbins P 2015 The Trickster science in McCarthy J, Bridge G, and Perreault T eds The Routledge Handbook of Political Ecology Routledge, London and New York 89-101 Robinson PA 2015 A history of bovine tuberculosis eradication policy in Northern Ireland. Epidemiology and Infection 143 3182-3195

Scott JC 1998 Seeing like a State: How Certain Schemes to Improve the Human Condition have Failed Yale University Press, New Haven and London

Shmueli DF 2008 Framing in geographical analysis of environmental conflicts: theory, methodology and three case studies Geoforum 39 2048-2061

Turner MD 2011 Production of environmental knowledge: scientists, complex natures, and the question of agency - Introduction in Goldman MJ, Nadasdy $\mathbf{P}$ and Turner MD eds Knowing Nature: Conversations at the Intersection of Political Ecology and Science Studies University of Chicago Press, Chicago and London 25-29

Whatmore S 2003 Generating materials in Pryke M, Rose G and Whatmore S eds Using Social Theory: Thinking Through Research SAGE Publications Ltd London, Thousand Oaks New Delhi 89-104

Wynne B 1996 May the sheep safely graze? A reflexive view of the expert-lay knowledge divide in Lash S, Szerszynski B and Wynne B eds Risk, Environment and Modernity: Towards a New Ecology Sage Publications, London, Thousand Oaks, New Delhi 44-83 